\title{
EFFECTIVENESS OF IMPLEMENTATION OF CONCEPT ATTAINMENT LEARNING MODEL TO INCREASE COGNITIVE LEARNING OUTCOMES OF HIGH SCHOOL STUDENTS
}

\author{
Dina Purwanti ${ }^{1)}$, Azizahwati $^{2)}$, Mitri Irianti ${ }^{3)}$ \\ ${ }^{1,2,3)}$ Physics Education, University of Riau \\ e-mail: dinapurwanti30@gmail.com \\ azizahwati@lecturer.unri.ac.id \\ mitri.irianti@lecturer.unri.ac.id
}

\begin{abstract}
This research aimed to determine the effectiveness of the implementation of concept attainment learning model to increase cognitive learning outcomes. The research method used is pre-experimental design with intact group comparison design. The research subjects were students of class XI SMA Negeri 9 Pekanbaru, in which class XI IPA 4 was an experimental class and class XI IPA $A_{5}$ was a control class. The experimental class uses a concept attainment learning model and a control class with a conventional learning. The data was obtained from cognitive learning outcomes test which given to students after the learning process was carried out. Data were analyzed descriptively to provide an overview of students cognitive learning outcomes including students absorption and learning effectiveness on indication of global warming material. The research result obtained were the average of students absorption ability in the experimental class was 76,94\% and 68,33\% for control class. Thus, can be concluded that the implementation of the concept attainment learning model was effective to increase student cognitive learning outcomes in SMA Negeri 9 Pekanbaru on the subject of global warming.
\end{abstract}

Keywords: concept attainment model, cognitive learning outcomes, global warming. 


\title{
EFEKTIVITAS PENERAPAN MODEL PEMBELAJARAN PENCAPAIAN KONSEP UNTUK MENINGKATKAN HASIL BELAJAR KOGNITIF SISWA SMA
}

\author{
Dina Purwanti ${ }^{1)}$, Azizahwati $^{2}$, Mitri Irianti ${ }^{3)}$ \\ ${ }^{1,2,3)}$ Pendidikan Fisika, Universitas Riau
}

\begin{abstract}
Abstrak
Penelitian ini bertujuan untuk mengetahui efektivitas penerapan model pembelajaran pencapaian konsep (concept attainment) dalam meningkatkan hasil belajar kognitif siswa. Metode penelitian yang digunakan yaitu pre-experimental design dengan rancangan intact group comparison. Subjek penelitian adalah siswa kelas XI SMA Negeri 9 Pekanbaru, yang mana kelas XI IPA 4 sebagai kelas eksperimen dan kelas XI IPA sebagai kelas kontrol. Kelas eksperimen menerapkan model pembelajaran pencapaian konsep dan kelas kontrol dengan pembelajaran konvensional. Instrumen pengumpulan data yang digunakan adalah tes hasil belajar kognitif yang diberikan kepada siswa setelah proses pembelajaran dilaksanakan. Data dianalisis secara deskriptif untuk memberikan gambaran hasil belajar kognitif siswa meliputi daya serap siswa dan efektivitas pembelajaran pada materi gejala pemanasan global. Hasil penelitian diperoleh daya serap rata-rata siswa pada kelas ekperimen 76,94\% dan kelas kontrol 68,33\%. Dengan demikian disimpulkan disimpulan bahwa penerapan model pembelajaran pencapaian konsep efektif untuk meningkatkan hasil belajar kognitif siswa di SMA Negeri 9 Pekanbaru pada materi pemanasan global.
\end{abstract}

Kata Kunci: model pencapaian konsep, hasil belajar kognitif, pemanasan global.

\section{Pendahuluan}

Salah satu faktor yang mempengaruhi pengembangan K13 adalah hasil capaian anakanak Indonesia dalam beberapa kali laporan yang dikeluarkan studi International Trends in International Mathematics and Science Study (TIMSS) dan Program for International Student Assessment (PISA) sejak tahun 1999 yang tidak memuaskan. Masalah utama dalam pembelajaran pada pendidikan formal adalah masih rendahnya daya serap siswa. Hal ini tampak dari rata-rata hasil belajar siswa yang senantiasa masih memprihatinkan. Prestasi tersebut merupakan hasil pem-belajaran yang masih bersifat konvensional dan tidak menyentuh ranah dimensi siswa itu sendiri, yaitu bagaimana sebenarnya konsep belajar itu (Trianto, 2010). Permasalahan tersebut cenderung terjadi pada mata pelajaran sains yang meliputi bidang Fisika, Kimia dan Biologi.

Berdasarkan informasi dari guru mata pelajaran Fisika kelas XI di SMAN 9 Pekanbaru, diketahui bahwa kemampuan mengingat siswa masih rendah. Hal ini dapat dilihat dari banyak siswa yang belum bisa menjelaskan kembali pengertian-pengertian berdasarkan materi yang dipelajari. Selain itu, siswa belum bisa membedakan serta menyebutkan contoh-contoh konkrit dari materi fisika yang dipelajari. Siswa hanya mendengarkan tanpa berperan aktif dalam pembelajaran. Pemberian soal tes setelah materi dipelajari, hanya mampu dikerjakan oleh sebahagian siswa. Hal inilah yang menyebabkan nilai siswa masih banyak yang di bawah KKM berdasarkan hasil tes fisika yang diberikan. Keadaan ini memperlihatkan bahwa hasil belajar fisika kelas XI SMAN 9 Pekanbaru belum sesuai dengan yang diharapkan.

Kurikulum 2013 telah mencantumkan materi pemanasan global sebagai materi pokok mata pelajaran fisika di SMA. Materi pemanasan global yang berlangsung dengan teknik hafalan membuat materi yang diterima oleh siswa tidak mampu tersimpan di memori dalam jangka waktu yang panjang sehingga pembelajaran kurang efektif. Hal ini sesuai dengan pendapat Winkel (2004) pada saat mempelajari materi untuk pertama kali seseorang mengolah bahan pengajaran yang kemudian disimpan dalam bentuk hafalan dan 
disimpan dengan bantuan daya ingat, sehingga pengetahuan dan pemahaman yang telah diperoleh mudah lupa dan bersifat sementara jika tidak mengulang kembali.

Untuk itu guru perlu melakukan perubahan dalam pembelajaran. Salah satu inovasi yang dapat dilakukan oleh guru adalah pemilihan model pembelajaran yang sesuai. Salah satu model pembelajaran yang dapat diterapkan adalah model pembelajaran pencapaian konsep (concept attainment). Kelebihan model ini yaitu memberikan tahapan mulai dari Penyajian data, pengujian pencapaian konsep dan analisis strategi pemikiran sebagaimana Tabel 1. Sanusi dalam Lilis Marina (2010) menyatakan bahwa model pembelajaran pencapaian konsep merupakan model pembelajaran yang mengajarkan konsep kepada siswa, dimana guru mengawali pengajaran dengan menyajikan data berupa contoh dan non-contoh terkait konsep yang akan dicapai. Siswa mendapat kesempatan melakukan identifikasi konsep untuk memunculkan definisi konsep berdasarkan ciri-ciri pada contoh. Model pembelajaran ini dapat digunakan sebagai suatu strategi pembelajaran, sebab dalam setiap fasenya dapat memfasilitasi guru dan siswa untuk menciptakan kegiatan pembelajaran yang mengutamakan perubahan konseptual pada siswa. Dengan demikian aktivitas dan hasil belajar siswa dapat meningkat.

Beberapa penelitian yang relevan adalah penelitian yang dilakukan oleh Rofi'ati (2014) yang penerapan model pencapaian konsep berbantu kartu bergambar, menunjukkan peningkatan hasil belajar siswa. Penelitian yang dilakukan Rahmi (2013) menyatakan bahwa model pembelajaran concept attainment mampu mengurangi miskonsepsi siswa, serta penelitian Winasmadi (2011) yang menerap kan model concept attainment menunjukkan hasil belajar siswa lebih baik daripada dengan cara konvensional. Dengan dasar tersebut, maka tujuan penelitian ini adalah untuk mengkaji perbedaan hasil belajar fisika siswa menggunakan model pembelajaran concept attainment dan pembelajaran konvensional di sekolah SMA pada materi pemanasan global.

Tabel 1 Fase-fase model pembelajaran pencapaian konsep (Concept Attainment)

\begin{tabular}{|c|c|c|}
\hline No & Tahap & Bentuk Kegiatan \\
\hline I & $\begin{array}{l}\text { Penyajian data dan } \\
\text { identifikasi konsep }\end{array}$ & $\begin{array}{l}\text { - Guru menyajikan contoh yang telah dilabeli (tiap } \\
\text { contoh sudah dikelompokkan sendiri-sendiri antara } \\
\text { contoh positif dan negatif). } \\
\text { - Siswa membandingkan ciri-ciri dalam contoh positif } \\
\text { dan contoh negatif. } \\
\text { - Siswa menjelaskan sebuah definisi menurut ciri-ciri } \\
\text { yang paling esensial. }\end{array}$ \\
\hline II & $\begin{array}{l}\text { Pengujian pencapaian } \\
\text { konsep }\end{array}$ & $\begin{array}{l}\text { - Siswa mengidentifikasi contoh-contoh tambahan yang } \\
\text { tidak dilabeli dengan tanda ya dan tidak. } \\
\text { - Guru menguji hipotesis, menamai konsep, dan } \\
\text { menyatakan kembali definisi menurut ciri-ciri yang } \\
\text { paling esensial. } \\
\text { - Siswa membuat contoh-contoh terkait materi. }\end{array}$ \\
\hline III & Analisis strategi pemikiran & $\begin{array}{l}\text { - Siswa mendeskripsikan pemikiran-pemikirannya. } \\
\text { - Siswa mendiskusikan peran sifat-sifat dan hipotesis- } \\
\text { hipotesis. } \\
\text { - Siswa mendiskusikan jenis dan ragam hipotesis. }\end{array}$ \\
\hline
\end{tabular}

Sumber: (Joyce, 2009). 
Oleh karena itu dilakukan penelitian dengan tentang efektivitas penerapan model pembelajaran pencapaian konsep (concept attainment) untuk meningkatkan hasil belajar kognitif siswa di SMA Negeri 9 Pekanbaru.

\section{Bahan dan Metode}

Penelitian ini dilakukan di SMA Negeri 9 Pekanbaru. Subjek penelitian ini adalah siswa kelas XI IPA 4 yang berjumlah 36 orang sebagai kelas eksperimen dan kelas XI IPA yang berjumlah 36 orang sebagai kelas kontrol. Penentuan dua kelas tersebut dilakukan dengan melihat hasil ulangan harian siswa, sehingga dua kelas yang diambil sebagai kelas eksperimen dan kelas kontrol adalah kelas yang memiliki nilai rata-rata ulangan harian yang cenderung sama.

Jenis penelitian yang dilakukan adalah penelitian pre-eksperimental design, dengan rancangan intact group comparison (Sugiyono, 2017). Kedua kelompok yang dijadikan subjek diasumsikan sama dalam semua segi yang relevan dan hanya berbeda dalam pemberian perlakuan. Kelas eksperimen diterapkan model pembelajaran pencapaian konsep (concept attainment), sedangkan kelas kontrol diterapkan pembelajaran konvensional. Kemudian dilanjutkan dengan pemberian posttest kepada kelas eksperimen dan kelas kontrol.

Tabel 2. Daya serap dan efektivitas pembelajaran

\begin{tabular}{cll}
\hline Interval & \multicolumn{1}{c}{ Kategori } & \multicolumn{1}{c}{ Kategori } \\
Daya Serap & \multicolumn{1}{c}{ Efektivitas } \\
\hline $85 \leq \mathrm{x} \leq 100$ & Sangat Baik & Sangat Efektif \\
$70 \leq \mathrm{x}<85$ & Baik & Efektif \\
$50 \leq \mathrm{x}<70$ & Cukup Baik & Cukup Efektif \\
$0 \leq \mathrm{x}<50$ & Kurang Baik & Kurang Efektif \\
\hline
\end{tabular}

Sumber: (Depdiknas, 2007).

Pengumpulan data dalam penelitian ini adalah tes hasil belajar kognitif yang bertujuan untuk mengetahui daya serap dan efektivitas pembelajaran. Tes hasil belajar berupa tes tertulis soal objektif. Tes hasil belajar kognitif yang diperoleh selanjutnya dianalisis menggunakan teknik analisis deskriptif. Analisis deskriptif digunakan untuk melihat gambaran hasil belajar kognitif siswa dengan menggunakan kriteria daya serap dan efektivitas pembelajaran. Adapun kategori daya serap dan efektivitas pembelajaran dapat dilihat pada Tabel 2 .

\section{Hasil dan Pembahasan}

Penelitian efektivitas penerapan model pencapaian konsep (concept attainment) untuk meningkatkan hasil belajar kognitif siswa kelas XI SMA pada materi gejala pemanasan global telah dilaksanakan di SMA Negeri 9 Pekanbaru. Data hasil penelitian dapat dilihat pada Tabel 3 dan Tabel 4.

Tabel 3. Daya serap rata-rata eksperimen

\begin{tabular}{|c|c|c|c|c|}
\hline \multirow[b]{2}{*}{ No } & \multirow{2}{*}{$\begin{array}{c}\text { Interval } \\
(\%)\end{array}$} & \multirow[b]{2}{*}{ Kategori } & \multicolumn{2}{|c|}{ Kelas Eksperimen } \\
\hline & & & $\%$ & $\begin{array}{c}\text { Jumlah } \\
\text { Siswa }\end{array}$ \\
\hline 1 & $85-100$ & $\begin{array}{c}\text { Sangat } \\
\text { Baik }\end{array}$ & 19,44 & 7 \\
\hline 2 & $70-84$ & Baik & 66,67 & 24 \\
\hline 3 & $50-69$ & $\begin{array}{c}\text { Cukup } \\
\text { Baik }\end{array}$ & 13,89 & 5 \\
\hline 4 & $0-49$ & $\begin{array}{c}\text { Kurang } \\
\text { Baik }\end{array}$ & 0,00 & 0 \\
\hline \multicolumn{2}{|c|}{ Rata-rata } & \multicolumn{3}{|c|}{76,94} \\
\hline \multicolumn{2}{|c|}{ Kategori } & & \multicolumn{2}{|l|}{ Baik } \\
\hline
\end{tabular}

Tabel 4. Daya serap rata-rata kontrol

\begin{tabular}{ccccc}
\hline No & $\begin{array}{c}\text { Interval } \\
(\%)\end{array}$ & Kategori & \multicolumn{2}{c}{ Kelas Kontrol } \\
$\%$ & $\begin{array}{c}\text { Jumlah } \\
\text { Siswa }\end{array}$ \\
\hline 1 & $85-100$ & $\begin{array}{c}\text { Sangat } \\
\text { Baik }\end{array}$ & 8,33 & 3 \\
2 & $70-84$ & $\begin{array}{c}\text { Baik } \\
\text { Cukup }\end{array}$ & 55,56 & 20 \\
3 & $50-69$ & $\begin{array}{c}\text { Baik } \\
2\end{array}$ & 27,78 & 10 \\
4 & $0-49$ & Kurang & 8,33 & 3 \\
\hline Rata-rata & \multicolumn{3}{c}{68,33} \\
\hline \multicolumn{3}{l}{ Kategori } & \multicolumn{3}{c}{ Cukup Baik } \\
\hline
\end{tabular}

Hasil belajar kognitif dapat dilihat dari daya serap siswa dalam memahami materi pembeljaran. Daya serap siswa adalah sebagai kemampuan siswa menyerap materi yang disajikan dalam proses pembelajaran (Azizahwati, 2009). Berdasarkan data Tabel 3 dan Tabel 4, daya serap rata-rata setelah dilakukan posttest untuk kelas eksperimen dan kelas kontrol terdapat perbedaan yaitu $8,61 \%$. Pada kelas eksperimen terdapat persentase 
hasil belajar siswa paling besar di kategori baik dengan jumlah siswa 24 orang dari 36 orang siswa yang ada, sedangkan pada kelas kontrol kebanyakan siswa juga berada pada kategori baik dengan jumlah siswa hanya 20 orang dari 36 orang. Namun pada kelas kontrol terdapat 3 orang siswa yang berada di kategori kurang baik. Sehingga dari hasil ini dapat menunjukkan efektivitas pembelajaran sesuai Tabel 5.

Tabel 5. Efektivitas pembelajaran

\begin{tabular}{cccc}
\hline No & Kelas & Daya Serap & Kategori \\
\hline 1 & Eksperimen & 76,94 & Efektif \\
2 & Kontrol & 68,33 & Cukup Efektif \\
\hline
\end{tabular}

Efektivitas pembelajaran melalui penerapan model pembelajaran pencapaian konsep dan pembelajaran konvensional mengacu pada daya serap rata-rata siswa kelas eksperimen dan kelas kontrol. Tabel 5 menunjukkan bahwa penerapan model pembelajaran pencapaian konsep pada materi pemanasan global di kelas XI SMA, walaupum belum optimal, namun dikatakan efektif. Hal ini ditunjukkan dari daya serap yang diperoleh kelas eksperimen lebih tinggi dibandingkan kelas kontrol yang hanya berada pada kategori cukup efektif.

Efektivitas pembelajaran tidak dapat terjadi dengan sendirinya, tetapi harus diupayakan dengan menciptakan suasana belajar yang kondusif karena efektivitas pembelajaran ditentukan oleh daya serap yang diperoleh siswa setelah proses pembelajaran berlangsung. Hal ini didukung oleh penelitian Budi Utami (2013) bahwa efektifitas suatu pembelajaran dapat ditentukan berdasarkan daya serap rata-rata siswa.

Tabel 3 dan Tabel 4 menunjukkan bahwa daya serap rata-rata kelas eksperimen yang menerapkan model pembelajaran pencapaian konsep berada pada kategori baik dan pembelajaran konvensional dengan kategori cukup baik. Dengan kata lain, daya serap rata-rata kelas dengan model pembelajaran pencapaian konsep lebih tinggi dari daya serap rata-rata kelas dengan pembelajaran konvensional. Perbedaan nilai daya serap disebabkan karena proses pembelajaran di kelas eksperimen menerapkan model pembelajaran pencapaian konsep, dimana dengan model pembelajaran seperti ini siswa dapat memahami isi materi pemanasan global tanpa menghafal. Model pembelajaran ini memberikan contoh dan non-contoh dalam kehidupan sehari-hari, sehingga dapat meningkatkan antusias siswa dalam mengikuti pembelajaran fisika pada materi pemanasan global. Kebanyakan siswa di sekolah menyepelekan materi pemanasan global ini, sehingga siswa hanya mengandalkan kemampuan hafalannya, yang sebenarnya tidak baik dalam proses pembelajaran. Maka dari itu dengan menggunakan model pencapaian konsep ini, siswa dapat lebih memahami materi pemanasan global tanpa menghafal melainkan dari contoh kejadian dalam kehidupan sehari-hari. Hal itu sesuai dengan penelitian Imam Budi et al. (2017) bahwa pembelajaran dengan model Concept Attainment memacu siswa untuk membentuk konsep yang matang terhadap pelajaran fisika, guna mendapatkan hasil yang maksimal. Selain itu, pembelajaran dengan model Concept Attainment dapat memacu siswa untuk mengembangkan konsep melalui contoh-contoh benar dan salah yang disajikan oleh guru hingga mencapai konsep yang diinginkan oleh guru.

Penerapan model pembelajaran pencapaian konsep mampu membuat siswa lebih aktif dalam proses pembelajaran, karena siswa dibimbing untuk menentukan dan mengelompokkan contoh-contoh yang diberikan guru melalui LKPD. Hal ini sejalan dengan penelitian yang dilakukan oleh Halimatus Sa'diyah et al. (2015) bahwa pada kelas yang menggunakan model pencapaian konsep, memiliki kegiatan pembelajaran yang dapat menumbuhkan interaksi timbal balik antara guru dengan siswa. Hasil kajian Winasmadi (2011) menyatakan bahwa keterlibatan siswa secara aktif dalam proses pembelajaran memberikan kesempatan untuk mengeksplorasi informasi, mengidentifikasi dan membangun sendiri konsep yang dipelajari.

Ada beberapa faktor yang menyebabkan kelas dengan model pencapaian konsep lebih baik dibandingkan kelas dengan pembelajaran konvensional. Hal ini sesuai dengan hasil kajian Susiyanto (2009), bahwa keunggulan pembelajaran fisika dengan model pencapaian konsep (Concept Attainment) dibandingkan pembelajaran konvensional adalah sebagai 
berikut: (1) Lebih tercipta suasana pembelajaran fisika yang menyenangkan dan menarik karena menggunakan media berupa contoh dan non-contoh dalam bentuk foto atau gambar yang dapat memicu rasa keingintahuan siswa untuk menghubungkan fenomena yang ada di lingkungan sekitar siswa, (2) antusias siswa lebih tinggi, (3) terjadi kerjasama dalam menjawab pertanyaan dari LKPD yang diberikan, (4) contoh dan non-contoh yang diberikan dapat mengefisien waktu yang digunakan pada proses pembelajaran fisika.

Berdasarkan hasil penelitian yang telah dilaksanakan, maka penerapan model pembelajaran pencapaian konsep di kelas XI SMA Negeri 9 Pekanbaru pada materi pemanasan global dikatakan efektif. Hasil penelitian yang didapatkan sesuai dengan penelitian yang dilakukan oleh Winasmadi (2011) yang menerapkan model concept attainment, menunjukkan hasil belajar siswa lebih baik daripada dengan cara konvensional.

Hasil belajar pada kelas eksperimen terdapat empat indikator yang daya serap rataratanya di bawah $70 \%$ dari sepuluh indikator yang disediakan yaitu indikator 1, 3, 5 dan 6 . Indikator pencapaian kompetensi nomor 1 menjelaskan efek rumah kaca pada ranah kognitif C2. Hasil analisis yang diperoleh terdapat 24 orang siswa yang menjawab benar dari 36 siswa dengan persentase $66,67 \%$, sehingga masih dikatakan belum memenuhi KKM. Hal ini dikarenakan penyampaian efek rumah kaca yang dilakukan peneliti hanya sebentar, tanpa menanyakan apakah siswa sudah memahami dengan baik atau belum. Seharusnya peneliti atau guru memberikan sedikit jeda dalam proses pembelajaran untuk menanyakan kepada siswa apakah sudah memahami pengertian dari efek rumah kaca tersebut.

Indikator pencapaian kompetensi nomor 3 menjelaskan proses terjadinya efek rumah kaca yang memiliki tingkat kesulitan pada ranah kognitif C2. Berdasarkan hasil analisis yang diperoleh terdapat 19 orang yang menjawab benar dengan persentase $52,78 \%$. Hal ini disebabkan, karena fasilitator menjelaskan proses terjadinya efek rumah kaca, hanya menggunakan gambar. Siswa seharusnya lebih tertarik jika proses terjadinya efek rumah kaca dijelaskan dengan menggunakan video.
Indikator pencapaian kompetensi nomor 5 memiliki tingkat kesulitan pada ranah kognitif yang lebih tinggi dari sebelumnya yaitu $\mathrm{C} 4$, karena siswa diminta untuk mampu menganalisis dampak efek rumah kaca. Hasil analisis menunjukkan bahwa hanya terdapat 14 orang siswa yang menjawab benar dengan persentase 38,89\%, Hasil ini jauh di bawah KKM, dikarenakan di dalam proses pembelajaran siswa tidak mendapatkan contoh dalam bentuk grafik, sehingga sebagian siswa belum terampil dalam membaca grafik. Seharusnya dalam proses pembelajaran, siswa diberikan beberapa contoh soal dalam bentuk grafik agar dapat melatih kemampuan siswa dalam menganalisis isi dari sebuah grafik.

Indikator pencapaian kompetensi nomor 6 pada ranah kognitif $\mathrm{C} 2$ dimana siswa diminta untuk mampu menjelaskan pengertian pemanasan global. Hasil analisis yang diperoleh menunjukkan bahwa terdapat 23 siswa yang menjawab benar dengan persentase $63,89 \%$. Jumlah siswa yang menjawab benar sudah melebihi separuh jumlah siswa yang ada di dalam kelas. Akan tetapi, butir soal ini masih berada pada kategori cukup baik dikarenakan siswa belum memahami secara optimal kondep pemanasan global.

\section{Kesimpulan dan Saran}

Berdasarkan hasil penelitian yang telah dilakukan, penerapan model pembelajaran pencapaian konsep pada materi pemanasan global di kelas XI IPA SMA Negeri 9 Pekanbaru diperoleh daya serap rata-rata kelas lebih tinggi dibandingkan daya serap rata-rata kelas dengan pembelajaran konvensional. Efektivitas pada kelas dengan pembelajaran pencapaian konsep berada pada kategori efektif. Dengan demikian, pembelajaran dengan penerapan model pencapaian konsep efektif untuk meningkatkan hasil belajar kognitif siswa di kelas XI IPA SMA Negeri 9 Pekanbaru.

Proses pembelajaran menggunakan model pencapaian konsep, diharapkan untuk mengoptimalkan pembelajaran pada setiap tahapan model pencapaian konsep agar hasil belajar mengalami peningkatan lebih baik. 
Perlu mengkondisikan dan menguasai kelas secara optimal ketika siswa belajar dalam kelompok, sehingga dapat dikendalikan memanajemen waktu lebih baik.

\section{Daftar Pustaka}

Azizahwati, 2009. Penerapan Strategi Mastery Learning untuk Mendeskripsikan Hasil Belajar Mahasiswa Program Studi Pendidikan Fisika FKIP UNRI pada Mata Kuliah Fisika Matematika I. Jurnal Geliga Sains, 3(2): 29-33.

Budi Utami, 2013. Penerapan Siklus Belajar 5E Disertai LKS untuk Peningkatan Kualitas Proses dan Hasil Belajar Kimia pada Materi Kelarutan dan Hasil Kali Kelarutan di kelas XI. Skripsi. Surakarta: Universitas Sebelas Maret.

Depdiknas, 2007. Petunjuk Pelaksanaan Proses Belajar Mengajar. Dirjen Dikdamen, Jakarta.

Halimatus Sa'diyah, Indrawati, \& Rif'ati Dina Handayani, 2015. Model Pembelajaran Concept Attainment disertai Metode Demonstrasi pada Pembelajaran IPAFisika di SMP. Jurnal Pembelajaran Fisika, 4(3).

Imam Budi, Trapsilo Prihandono, \& Bambang Supriadi, 2017. Penerapan Model Concept Attainment disertai Teknik Concept Mapping dalam Pembelajaran Fisika di MA. Jurnal Pembelajaran Fisika, 6(1).

Joyce, Bruce, 2009. Models Of Teaching: Model-model Pembelajaran, trjm. Achmad Fawaid dan Ateilla Mirza. Pustaka Pelajar, Yogyakarta.
Lilis Marina, 2010. Pengaruh Model Pembelajaran Pencapaian Konsep terhadap Pemahaman Konsep Matematika Siswa. Skripsi Jurusan Pendidikan Matematika Fakultas Tarbiyah dan Keguruan UIN Syarif Hidayatullah, Jakarta.

Rahmi, 2013. Pengaruh Model Pembelajaran Pencapaian Konsep dengan Menggunakan Peta Pikiran sebagai Upaya Mengurangi Miskonsepsi Siswa. Jurnal INPAFI, 1(2).

Rofi'ati, 2014. Penerapan Model Pencapaian Konsep Berbantu Kartu Bergambar terhadap Hasil Belajar pada Materi Sel di SMA. Unnes Journal of Biology Education, 3(2).

Sugiyono, 2017. Metode Penelitian Kuantitatif, Kualitatif, dan $R \& D$. Alfabeta, Bandung.

Susiyanto, 2009. Pengaruh Penggunaan Model Pembelajaran Pencapaian Konsep (Concept Attainment) dengan Bantuan Media Foto terhadap Hasil Belajar Materi Pokok Hidrokarbon Siswa Kelas X SMA 2 Semarang. Skripsi. FMIPA Universitas Negeri Semarang, Semarang.

Trianto, 2010. Mendesain Model Pembelajaran Inovatif-Progresif. Kencana, Jakarta.

Winasmadi, 2011. Pengembangan Perangkat Pembelajaran dengan Model Concept Attaiment berbantuan CD Interactive pada Kelas VII. Jurnal Penelitian Pendidikan, 1(2).

Winkel, 2004. Psikologi Pendidikan dan Evaluasi Belajar. PT. Grasindo Pustaka Utama, Jakarta. 